\title{
Turismo Tourism
}

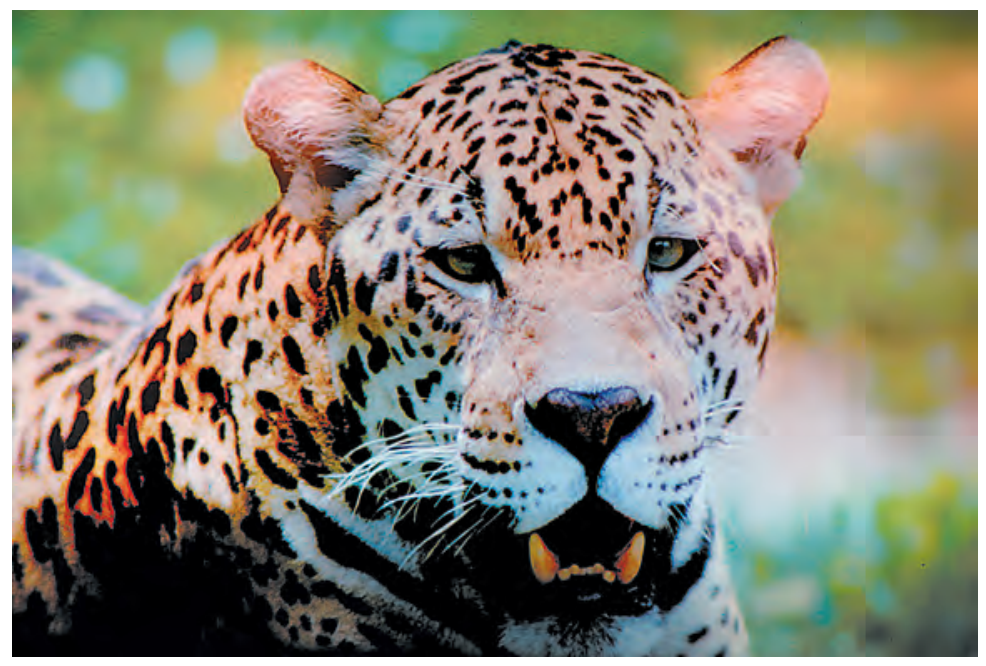

Onça Pintada, 2008

Spotted Jaguar

Airton Felipeli 


\section{Tourism}

\section{Fostering Tourism in National Plans of Tourism}

In Brazil, Tourism is classified as a sector of the economy, and, as such, it is entitled to special consideration from the government in the form of public policies and investments aimed at its development. A major objective of Tourism expansion is to bring positive social and economic results for the country.

The Tourism portfolio has been part of the federal government since 2003, a year marked by the creation of the Ministry of Tourism and the publication of the National Plan of Tourism 2003-2007 and, later, of the National Plan of Tourism 2007-2010: Brazilian Routes. The latter was mainly aimed at the diversification of tourism services offered in Brazil in order to reach goals such as the increase of the demand for domestic and international tourism in different Brazilian states.

The subsequent plans of tourism were aimed at the planning and organization of three international sports events held in Brazil: FIFA Confederations Cup 2013; 2014 FIFA World Cup and Rio 2016 Olympic Games. Therefore, the analysis of tourism-related statistics in Brazil will follow the premise that these big events did foster Tourism in the country. That, combined with the organization and diversification of the national offer, may enable the sector to bring development to different tourist regions in the country.

\section{Current scenario of tourism in Brazil}

One of the indicators adopted to evaluate and monitor the development of Tourism in a given destination, region or country is the arrival of tourists. From this perspective, the data presented in Table 16.1 help in the analysis of tourist flow in the aforementioned 


\section{Turismo}

\section{O fomento do Turismo nos Planos Nacionais de Turismo}

O Turismo no Brasil se caracteriza como setor econômico e, deste modo, passível de receber do poder público a atenção especial na forma de políticas públicas e investimentos para o seu fomento, com o intuito de desenvolver a atividade para que a mesma gere resultados econômicos e sociais positivos para o País.

A partir de 2003, o Turismo passou a ter pasta própria em nível federal com a criação do Ministério do Turismo e a publicação do Plano Nacional de Turismo 2003-2007 e posteriormente, o Plano Nacional de Turismo 2007-2010: Roteiros do Brasil, que objetivava, principalmente, a diversificação da oferta turística do Brasil para alcançar metas como o aumento da demanda turística doméstica e internacional nos diferentes Estados brasileiros.

Os planos de turismo subsequentes objetivaram o planejamento e a organização do Brasil para sediar três eventos esportivos internacionais: a Copa das Confederações FIFA 2013; a Copa do Mundo de Futebol FIFA 2014 e os Jogos Olímpicos Rio 2016. Deste modo, a análise das estatísticas relacionadas ao Turismo no País terá como pano de fundo a perspectiva de que estes megaeventos se caracterizaram como propulsores do Turismo no Brasil, que alinhados à organização e à diversificação da oferta turística nacional, tornaria o Turismo setor gerador de desenvolvimento para as diferentes regiões turísticas do País.

\section{O panorama geral do Turismo no Brasil}

O desenvolvimento do Turismo em um destino, região ou país, tem como um dos indicadores de avaliação e monitoramento a chegada de turistas no local em análise. Nesta perspectiva, a Tabela 16.1 apresenta dados que contribuem para um diagnóstico de como se deu o fluxo turístico no Brasil entre os referidos anos. Ba- 
period. According to the table, there was an increase of $10.6 \%$ in the number of tourists in Brazil from 2013 to 2014, which may reflect the efforts made towards the growth of tourism demand, especially considering the relevant sports events held in the country. Although the Confederations Cup and the Soccer World Cup are internationally-famous events and very appealing to the media, the entry of tourists in this period did not increase significantly, in spite of Brazil's hosting of the 2014 World Cup. On the other hand, as there was a decrease of $1.93 \%$ in tourist arrivals in Brazil from 2014 to 2015, we see that the World Cup has left a positive legacy for Tourism. We have been able to keep $8.7 \%$ of the flow of international tourists in the year succeeding the World Cup.

Also according to Table 16.1, among the main countries in terms of tourist visits to Brazil are Argentina, in South America, with 29.84\% of the overall tourist flow; the United States, in North America, with 9.84\%, and Germany, in Europe, which accounted for $3.92 \%$ of the visits, considering the average number of tourists in 2013, 2014 and 2015. The proximity between Brazil and other South American countries facilitates entry, both in terms of access (by air or road) and of prices paid for tourism products and services. Because of these characteristics, the entry of tourists from South America increased 6.7\% between 2013 and 2014, and 9.15\% between 2014 and 2015.

Even so, among the main issuers of tourists by continent, Argentina was the only one to record an increase in the number of tourists sent between 2013 and 2015. Another fact to be highlighted regarding tourist flow in the country refers to the other three most important issuers. Tourist entry rose between 2013 and 2014 and fell from 2014 to 2015, and, in 2015, the number of tourist arrivals from the United States, Germany and France was smaller than in 2013. These results point to the volatility of Tourism, since this phenomenon is influenced by the social, economic and political contexts of countries where tourists come from and of countries they visit. In this respect, the economic and political crisis faced by Europe, with economic retraction and stagnation, the subsequent social crises and the austerity policies adopted, helped change the behavior of European families. That is also true about the United States, which, not being able to recover from the economic crisis initiated in 2008, may have contributed to reduce tourist flow in Brazil between the years 2014 and 2015. 
seados nos dados apresentados na referida tabela, constatamos um aumento de 10,6\% do número de turistas no Brasil em 2014 com relação a 2013, fato este que está em consonância com o esforço de aumentar a demanda turística, principalmente a partir da realização de relevantes eventos esportivos. No entanto, se analisarmos a Copa das Confederações e a Copa do Mundo de Futebol como eventos de alcance mundial e com forte apelo midiático, constatamos um aumento pouco significativo na entrada de turistas neste período, levando em consideração que 2014 foi o ano da realização da Copa do Mundo no Brasil. Por outro lado, entendendo que do ano de 2014 para 2015 houve uma diminuição de 1,93\% na chegada de turistas que visitaram o País, constatamos que a Copa do Mundo deixou um saldo positivo para o Turismo uma vez que conseguimos manter $8,7 \%$ do fluxo de turistas internacionais no ano seguinte à Copa do Mundo.

Ainda de acordo com a Tabela 16.1, dentre os destinos emissores de maior expressividade no envio de turistas para o Brasil estão a Argentina na América do Sul com 29,84\% do fluxo total de turistas; seguido dos Estados Unidos, na América do Norte, com 9,84\%; e a Alemanha no continente Europeu, que compreendeu 3,92\% deste fluxo, considerando a média de turistas dos anos 2013, 2014 e 2015. Acreditamos que a proximidade com o Brasil dos países da América do Sul facilita a entrada no País, tanto em termos de infraestrutura de acesso (aéreo e rodoviário) como em relação a preços dos serviços e produtos turísticos. Devido a estas facilidades, a entrada de turistas vindos dos países da América do Sul cresceu 6,7\% entre 2013 e 2014, e 9,15\% entre 2014 e 2015.

Por outro lado, dos principais destinos emissores de turistas por continente, somente a Argentina apresentou um aumento do número de turistas entre os anos de 2013 a 2015. Outro dado que chama atenção com relação ao fluxo de turistas no País diz respeito aos outros três destinos mais expressivos emissores de turistas, uma vez que houve o aumento da entrada de turistas entre 2013 e 2014 e uma retração de 2014 a 2015, de modo que em 2015 o número de entrada de turistas dos Estados Unidos, Alemanha e França foi menor que em 2013. Tal estimativa sinaliza a volatilidade do Turismo, tendo em vista que este fenômeno é influenciado pelos contextos social, econômico e político, tanto dos países emissores de turistas, como do país receptor. Neste sentido, a crise econômica e política pelo qual passava a Europa com a retração e estagnação econômica, gerando crises sociais com políticas austeras que mudaram o comportamento das famílias europeias, assim como os Estados Unidos, que não apresentava uma recuperação da crise econômica desencadeada desde 2008, parecem ter influenciado a diminuição de turistas no Brasil entre os anos de 2014 e 2015. 
With reference to the number of foreign tourists in 2014 and 2015, data in Table 16.1 indicate that the major sport events Confederations Cup and World Cup did not generate the expected positive impacts, opposite to what had been considered to justify financial investments in Brazil's preparation for the competitions. One example of this difference is the decrease of real tourist demand from North America and Europe. We tend to believe that more effective strategies should have been adopted in order to combine the promotion of those two events with the qualification and diversification of tourist offer in Brazil. It would have been possible to align initiatives already fostered by the Ministry of Tourism by means of public policies with the opportunities of worldwide visibility brought about by the aforementioned events.

Among the most visited Brazilian cities, listed in Graph 16.1, Rio de Janeiro, Florianópolis, São Paulo and Foz do Iguaçu were the most visited between 2013 and 2014, though a reduction in the number of tourists visiting São Paulo (-9.7\%) was observed from 2014 to 2015. The decrease of tourist flow caused São Paulo to fall from the second to the fourth position in the ranking, after Florianópolis and Foz do Iguaçu, respectively. Another interesting fact about the data in Graph 16.1 is the decrease in the number of visitors in Rio de Janeiro (-12.6\%) and São Paulo (-9.7\%) from 2014 to 2015. It is believed that these cities, being hosts of the 2014 World Cup, had an increased flow of tourists during the event, but did not keep that status for long afterwards. Another aspect that should be highlighted is that out of the ten host-cities of the World Cup, only Rio de Janeiro (45.2\%), São Paulo (19.4\%) and Salvador (7.3\%) are among the most visited ones in 2014. So, it seems that although Florianópolis and Foz do Iguaçu did not host the games, they ended up benefiting from the tourist demand from South America because of their location in frontier areas.

Among the Brazilian states with the biggest number of tourist arrivals is São Paulo, a highlight in the first position in 2013, 2014 and 2015, followed by Rio de Janeiro in the three years analyzed. In 2013, Paraná was the third state in terms of number of tourists, and in 2014 and 2015, Rio Grande do Sul stood out in the third position as the entrance gate to Brazil, as shown in Table 6.2. From a comparison of data on the arrival of tourists with those on the most visited cities, we can infer that São Paulo is the most important entrance gate to Brazil and the main city in terms of tourist flow distribution to other states. The increased entry of tourists in Rio Grande 
Além disso, a análise dos dados da Tabela 16.1, no que diz respeito ao número de turistas estrangeiros em 2014 e 2015 leva a inferir que muito do que se esperava de benefício trazido pelos megaeventos esportivos Copa das Confederações e Copa do Mundo, para justificar inclusive os aportes financeiros investidos na preparação do Brasil para sediar estes eventos, não geraram os impactos positivos anunciados, a exemplo da diminuição da demanda turística real, advinda da América do Norte e da Europa. Sendo assim, acreditamos que faltaram estratégias mais eficazes que alinhassem a realização destes dois eventos esportivos com a qualificação e a diversificação da oferta turística no País, já estimuladas pelo Ministério do Turismo através das políticas públicas, com as oportunidades de visibilidade mundial que os eventos esportivos poderiam gerar.

Dentre as cidades mais visitadas no Brasil, cujos dados estão no Gráfico 16.1, entre os anos de 2013 a 2014 estão o Rio de Janeiro, Florianópolis, São Paulo e Foz do Iguaçu, sendo que de 2014 a 2015, ocorre uma queda de turistas visitando São Paulo (-9,7\%). Esta queda no fluxo de turistas fez com que São Paulo caísse do segundo para o quarto lugar em entrada de turistas, ficando atrás de Florianópolis e Foz do Iguaçu, respectivamente. Outro fato que chama atenção nos dados apresentados no gráfico diz respeito à queda no número de visitantes de 2014 a 2015 no Rio de Janeiro $(-12,6 \%)$ e São Paulo (-9,7\%). Acredita-se que estas cidades, por serem cidades-sede do evento esportivo Copa do Mundo de 2014, aumentaram o fluxo de turistas durante o evento, mas não conseguiram mantê-lo após o evento. Outro aspecto que merece destaque com relação ao evento Copa do Mundo é que das dez cidadessede da Copa, somente Rio de Janeiro (45,2\%), São Paulo (19,4\%) e Salvador (7,3\%) aparecem como as cidades mais visitadas pelos turistas estrangeiros para lazer em 2014. Assim, entende-se que Florianópolis e Foz do Iguaçu, mesmo não sediando os jogos, se beneficiaram como destinos receptores do Brasil, principalmente pela demanda sul-americana uma vez que estão próximas às regiões de fronteira.

Dentre os Estados brasileiros com maior volume de chegada de turistas destaca-se em primeiro lugar São Paulo, tanto em 2013 como em 2014 e 2015, seguido de Rio de Janeiro também nos três anos em análise. Em 2013, o Paraná foi o terceiro Estado a receber o maior número de chegada de turistas, e em 2014 e 2015 o Rio Grande do Sul se destacou ficando na terceira posição como portão de entrada no Brasil, como atesta da Tabela 6.2. Comparando os dados de entrada de turistas com os das cidades mais visitadas no Brasil, podemos inferir que São Paulo se caracteriza como o mais importante portão de entrada de turistas no Brasil e de distribuição do fluxo turístico para os outros Estados brasileiros. Acredita-se ainda que este aumento do 
do Sul in 2014 is believed to have resulted from the fact that Porto Alegre had hosted the World Cup that same year.

Another important aspect in the analysis of Tourism is the qualification and legalization of tourist offer due to actions of the Ministry of Tourism. Within the realm of tourist offer are travel agencies, that is, companies specialized in the trade of services of emission and reception of tourists. In this respect, CADASTUR, the system for registering people and companies that work in the tourism sector, is an important means to check the levels of organization and formalization of enterprises and persons working in the Tourism sector in the Brazilian states. Table 16.3 shows that São Paulo has the biggest number of listed agencies from all Brazilian states $(5,417)$, followed by Rio de Janeiro $(2,678)$. Minas Gerais, Paraná and Rio Grande do Sul are in the third, fourth and fifth positions, respectively. The smallest numbers of agencies listed are found in Amapá (67), Tocantins and Roraima (69, each). A comparison between data about the most visited states in Brazil and the number of agencies listed in the CADASTUR system shows a relationship between tourist flow and the formalization and qualification of tourist enterprises. States with bigger demand for tourism have the biggest number of agencies listed.

Another relevant aspect in the evaluation of the tourism phenomenon refers to expenditure and revenue in the balance of payments of the tourism account. That account is the ratio between the expenditures on foreign travel by Brazilians and the expenditures of tourists visiting Brazil. Graph 16.2 presents a gradual increase of expenditures of tourist account from 2008 to 2014, with a retraction in 2015 only, which means that between 2008 and 2014 Brazilians spent more traveling abroad than foreigners visiting Brazil. It is worth mentioning that 2013 and 2014 were marked by the two aforementioned sports events which stimulated domestic and international tourism in the Brazilian territory. Regarding revenues in the balance of payments, Table 16.3, which refers to the expenditures of tourists in Brazil, shows a gradual, but not very significant, increase from 2008 to 2014 and a decrease in 2015 over the 2014 figure. We believe Tourism growth indexes in Brazil result from the dedication of federal authorities to the planning and organization of this sector at national level, culminating in Brazil's hosting of sports events in 2013 and 2014, which led to a major flow of international tourists visiting the country and encouraged domestic trips as well. 
número de entrada de turistas no Rio Grande do Sul em 2014 deve-se ao fato de Porto Alegre ter sido cidade-sede na Copa do Mundo neste mesmo ano.

Outro ponto importante para se analisar o Turismo é a qualificação e a legalização da oferta turística como ação do próprio Ministério do Turismo. Dentre um dos elementos que fazem parte da oferta turística estão as agências de viagem, que são as empresas especializadas na comercialização dos serviços turísticos de emissão e de recepção de turistas. Neste sentido, o CADASTUR, cadastro de pessoas físicas e jurídicas que atuam nos diferentes setores do Turismo, se configura como um importante meio para se verificar como está a organização e a formalização dos empreendimentos e pessoas que trabalham com o Turismo nos Estados brasileiros. A Tabela 16.3 aponta que São Paulo é o Estado brasileiro que apresenta o maior número de agências cadastradas (5417), seguido do Rio de Janeiro (2 678). Os Estados de Minas Gerais, Paraná e Rio Grande do Sul estão em terceiro, quarto e quinto lugar, respectivamente, com o maior número de agências cadastradas no CADASTUR. Já os Estados com o menor número de agências cadastradas são Amapá (67 agências), Tocantins e Roraima (ambas com 69 agências cadastradas). Se compararmos os dados dos Estados mais visitados do País, com o número de agências de viagens formalizadas no sistema CADASTUR, podemos inferir que a formalização e a qualificação dos empreendimentos turísticos são influenciadas pelo fluxo turístico, uma vez que os Estados com maior demanda turística real são os mesmos com o maior número de agências cadastradas.

Um dado também relevante na avaliação do fenômeno turístico diz respeito às despesas e receitas na balança de pagamento da conta turismo. A conta turismo é a relação entre os gastos de brasileiros quando viajam para outros países e os gastos de estrangeiros quando visitam o Brasil. O Gráfico 16.2 demonstra um aumento gradual das despesas na balança de pagamentos da conta turismo de 2008 a 2014, havendo uma retração somente em 2015, ou seja, entre os anos de 2008 e 2014 os brasileiros gastaram mais em viagens no exterior que os estrangeiros no Brasil. Ressalte-se que 2013 e 2014 foram os anos de realização dos dois megaeventos esportivos anteriormente mencionados, fatos estes que estimularam as viagens turísticas internacionais e domésticas em território brasileiro. No que diz respeito às receitas na balança de pagamento, a Tabela 16.3, que se refere aos gastos de turistas no Brasil, demonstra um aumento gradual, mas não muito expressivo de 2008 a 2014, e uma diminuição em 2015 em relação a 2014. Acreditamos que estes índices de crescimento do Turismo no Brasil decorrem de uma maior atenção das instâncias federais no planejamento e na organização do Turismo no País através da implantação de políticas públicas desdobradas nos Planos Nacionais de Turismo, culminando com a realização dos eventos esportivos ocorridos em 2013 e 2014, que geraram um maior fluxo de turistas internacionais visitando o País, além de terem sido estimuladores também das viagens domésticas. 
The exchange rate also plays a role in the choice of tourism trips. Depreciation of national currency leads to a decrease of Brazilian's purchasing power in foreign countries, whereas foreign visitors, with a stronger currency, experience the opposite in Brazil. Thus, Brazilians are more susceptible to currency fluctuation. For this reason, appreciation of the North-American currency in 2012 led to the decrease of expenditure in the Brazilian Tourism Account, starting that same year, as shown in Graph 16.4.

That confirms the susceptibility of Tourism to changes in the economic, political and socio-cultural scenario at local and global levels. It also evidences the importance of offering the public a diversity of tourist destinations, so that different segments of tourism demand can be covered at different times of the year. Data point to the necessity of stimulating domestic tourism in Brazil, as a relevant strategy to adjust the balance of payments of the tourism account and to provide services to potential consumers of domestic tourism services who still prefer foreign destinations.

In future studies on the legacy of the World Cup, it will be important to observe the decrease, maintenance or increase of tourist flow in the years following the 2014 World Cup and the 2016 Olympic Games in Rio de Janeiro, so as to come to a conclusion about the consolidation of Brazil as an international tourist destination. Studies should investigate more deeply the relationship between the implementation of public policies in Tourism and the development of the tourism phenomenon in different regions, with more regular space-time coverage.

Translated by: Aline Milani Romeiro Pereira 
Além disso, a taxa de cambio exerce o poder de causalidade nas viagens turísticas, sendo inclusive fator de decisão na escolha dos destinos turísticos. À medida que a moeda nacional se desvaloriza, os brasileiros diminuem o seu poder de consumo nos países estrangeiros, ao passo que os estrangeiros, tendo sua moeda mais valorizada, aumentam seu poder de compra no Brasil. Assim, os brasileiros estão mais suscetíveis às variações cambiais. Por isso, a valorização da moeda norte-americana em 2012 levou à diminuição das despesas na conta turismo do Brasil, a partir deste mesmo ano, como demonstra o Gráfico 16.4.

Tal fato comprova o quanto o Turismo está suscetível aos contextos econômico, político e sociocultural global e local. Esta característica possibilita entender a importância de diversificar a oferta turística dos destinos, de modo a atender diferentes segmentos da demanda turística e em diferentes épocas do ano. Tais dados apontam para a necessidade de fomentar o Turismo doméstico no Brasil, entendendo esta estratégia como relevante intervenção para equilibrar a balança de pagamento da conta turismo, além de possibilitar o atendimento de um público que se caracteriza como demanda potencial do turismo doméstico, mas que prefere viajar para destinos turísticos localizados em outros países.

Dentre os estudos que visem analisar o legado deixado pela Copa do Mundo, é importante que se verifique a queda, a manutenção ou o aumento do fluxo turístico nos anos posteriores a Copa do Mundo de 2014 e aos Jogos Olímpicos do Rio de Janeiro de 2016, para verificar se estes eventos cumpriram o objetivo de consolidar o Brasil como destino turístico no mercado internacional. Além disso, é importante que se aprofundem os estudos sobre a relação entre implementação das políticas públicas de Turismo e o desenvolvimento do fenômeno turístico nas diferentes regiões do Brasil, promovendo a constância destes estudos em uma escala espaço-temporal.

\section{Isabelle de Fátima Silva Pinheiro}

Turismóloga. Especialista em Docência no Ensino Superior. Mestre e Doutora em Recursos Naturais pela Universidade Federal de Campina Grande/UFCG. Docente do Curso de Turismo da Universidade Federal de Mato Grosso do Sul/UFMS- Campus de Aquidauana.

Travel and Tourism Consultant. Specialist in Higher Education Teaching. Master and PhD in Natural Resources from the Federal University of Campina Grande/UFCG. Professor of the Faculty of Tourism at the Federal University of Mato Grosso do Sul/UFMS - Aquidauana Campus. 
Tabela 16.1 - Chegadas de turistas no Brasil - 2013-2015

Table 16.1 - Tourist arrivals to Brazil - 2013-2015

(continua/to be continued)

\begin{tabular}{|c|c|c|c|}
\hline \multirow{2}{*}{$\begin{array}{l}\text { País de residência } \\
\text { permanente/ } \\
\text { Country of } \\
\text { permanent residence }\end{array}$} & \multicolumn{3}{|c|}{$\begin{array}{l}\text { Chegadas de turistas/ } \\
\text { Tourist arrivals }\end{array}$} \\
\hline & 2013 & 2014 & 2015 \\
\hline Total/ Total & 5813342 & 6429852 & 6305838 \\
\hline África/Africa & 94832 & 128252 & 110983 \\
\hline América Central/Central America & 52520 & 61968 & 53709 \\
\hline América do Norte/North America & 737175 & 844969 & 734450 \\
\hline Canadá/Canada & 67610 & 78531 & 68293 \\
\hline Estados Unidos/United States & 592827 & 656801 & 575796 \\
\hline México/Mexico & 76738 & 109637 & 90361 \\
\hline América do Sul/South America & 2936753 & 3133629 & 3420349 \\
\hline Argentina/Argentina & 1711491 & 1743930 & 2079823 \\
\hline Bolívia/Bolivia & 95028 & 95300 & 108149 \\
\hline Chile/Chile & 268203 & 336950 & 306331 \\
\hline Colômbia/Colombia & 116461 & 158886 & 118866 \\
\hline Paraguai/Paraguay & 268932 & 293841 & 301831 \\
\hline Peru/Peru & 98602 & 117230 & 113078 \\
\hline Uruguai/Uruguay & 262512 & 223508 & 267321 \\
\hline Venezuela/Venezuela & 68309 & 108170 & 80488 \\
\hline Outros/Other countries & 47215 & 55814 & 44462 \\
\hline Ásia/Asia & 300998 & 332585 & 299270 \\
\hline Japão/Japan & 87225 & 84636 & 70102 \\
\hline Outros/Other countries & 213773 & 247949 & 229168 \\
\hline
\end{tabular}


Tabela 16.1 - Chegadas de turistas no Brasil - 2013-2015

Table 16.1 - Tourist arrivals to Brazil - 2013-2015

(conclusão/concluded)

\begin{tabular}{|c|c|c|c|}
\hline \multirow{2}{*}{$\begin{array}{l}\text { País de residência } \\
\text { permanente/ } \\
\text { Country of } \\
\text { permanent residence }\end{array}$} & \multicolumn{3}{|c|}{$\begin{array}{c}\text { Chegadas de turistas/ } \\
\text { Tourist arrivals }\end{array}$} \\
\hline & 2013 & 2014 & 2014 \\
\hline Europa/Europe & 1636569 & 1847834 & 1631514 \\
\hline Alemanha/Germany & 236505 & 265498 & 224549 \\
\hline Áustria/Austria & 25929 & 28532 & 26575 \\
\hline Bélgica/Belgium & 33356 & 42964 & 34423 \\
\hline Espanha/Spain & 169751 & 166759 & 151029 \\
\hline França/France & 224078 & 282375 & 261075 \\
\hline Holanda/Netherlands & 69187 & 81655 & 66870 \\
\hline Inglaterra/England & 169732 & 217003 & 189269 \\
\hline Itália/ltaly & 233243 & 228734 & 202015 \\
\hline Portugal/Portugal & 168250 & 170066 & 162305 \\
\hline Suiç̧a/Switzerland & 68390 & 80277 & 70319 \\
\hline Outros/Other countries & 238148 & 283971 & 243085 \\
\hline Oceânia/Oceania & 54281 & 80447 & 55421 \\
\hline Não especificado/Unspecified & 214 & 168 & 142 \\
\hline
\end{tabular}

Fonte/Source: Anuário estatístico de turismo 2016. Brasília, DF: Ministério do Turismo, v. 43, 2016. Ano base 2015. Disponível em/Available from: <http://dadosefatos.turismo.gov.br/2016-02-04-11-53-05. html>. Acesso em: maio 2017/Cited: May 2017. 
Tabela 16.2 - Chegadas de turistas no Brasil, por Unidades da Federação de acesso - 2013-2015

Table 16.2 - Tourist arrivals to Brazil, by Federation Unit of arrival - 2013-2015

\begin{tabular}{|c|c|c|c|}
\hline \multirow{2}{*}{$\begin{array}{l}\text { Unidades da Federação de acesso/ } \\
\text { Federation Unit of arrival }\end{array}$} & \multicolumn{3}{|c|}{$\begin{array}{c}\text { Chegadas de turistas/ } \\
\text { Tourist arrivals }\end{array}$} \\
\hline & 2013 & 2014 & 2015 \\
\hline Total/Total & 5813342 & 6429852 & 6305838 \\
\hline Amazonas & 32993 & 50032 & 50290 \\
\hline Pará & 13269 & 14813 & 20708 \\
\hline Pernambuco & 75174 & 78075 & 66232 \\
\hline Bahia & 128838 & 145660 & 151660 \\
\hline Ceará & 84119 & 85025 & 78711 \\
\hline Rio de Janeiro & 1207800 & 1597153 & 1375978 \\
\hline Minas Gerais & 46639 & 50916 & 47929 \\
\hline São Paulo & 2219513 & 2219917 & 2248811 \\
\hline Paraná & 839728 & 837046 & 758973 \\
\hline Rio Grande do Norte & 35888 & 38014 & 28580 \\
\hline Rio Grande do Sul & 782887 & 907669 & 1080478 \\
\hline Mato Grosso do Sul & 41523 & 61999 & 56601 \\
\hline Santa Catarina & 175023 & 156976 & 149133 \\
\hline Distrito Federal/Federal District & 74287 & 100063 & 107208 \\
\hline Outros/Others & 55661 & 86494 & 84546 \\
\hline
\end{tabular}

Fonte/Source: Anuário estatístico de turismo 2016. Brasília, DF: Ministério do Turismo, v. 43, 2016. Ano base 2015. Disponível em/Available from: <http://dadosefatos.turismo.gov.br/2016-02-04-11-53-05.htn Acesso em: maio 2017/Cited: May 2017. 
Tabela 16.3 - Agências de turismo cadastradas no CADASTUR - 2015

Table 16.3 - Travel and tourism agencies listed in CADASTUR - 2015

Unidades da Federação/

Federation Units
Agências/

Agencies

Brasil/Brazil

19458

Rondônia

Acre

Amazonas

Roraima

Pará

Amapá

Tocantins

Maranhão

Piauí

Ceará

Rio Grande do Norte

Paraíba

Pernambuco

Alagoas

Sergipe

Bahia

Minas Gerais

1550

Espírito Santo

Rio de Janeiro

São Paulo

Paraná

Santa Catarina

Rio Grande do Sul

Mato Grosso do Sul

Mato Grosso

Goiás

Distrito Federal/Federal District

Fonte/Source: Anuário estatístico de turismo 2016. Brasília, DF: Ministério do Turismo, v. 43, 2016. Ano base 2015. Disponível em/Available from: <http://dadosefatos.turismo.gov.br/2016-02-04-11-53-05. html>. Acesso em: maio 2017/Cited: May 2017. 


\section{Gráfico 16.1 - Dez cidades brasileiras mais visitadas pelos turistas estrangeiros para lazer - 2014-2015}

Graph 16.1 - Ten most visited Brazilian cities by foreigners

for tourism - 2014-2015

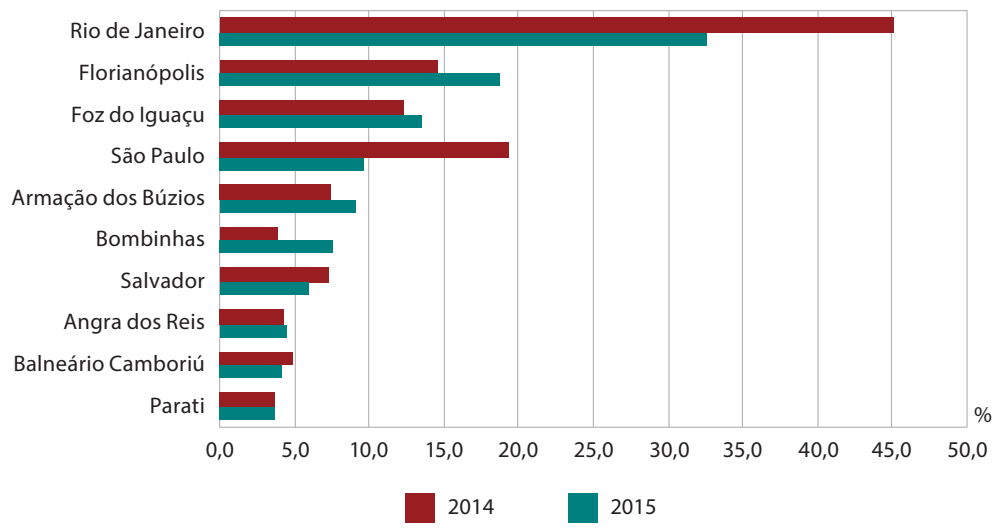

Fonte/Source: Estudo da demanda turística internacional 2011-2015. Brasília, DF: Ministério do Turismo, 2016. Disponível em/Available from: <http://dadosefatos.turismo.gov.br/2016-02-04-11-54-03/demandatur\%C3\%ADstica-internacional.html>. Acesso em: maio 2017/Cited: May 2017.

\section{Gráfico 16.2 - Despesa da balança de pagamentos da conta turismo - 2008-2015 \\ Graph16.2 - Expenditure in the balance of payments of tourism account - 2008-2015}

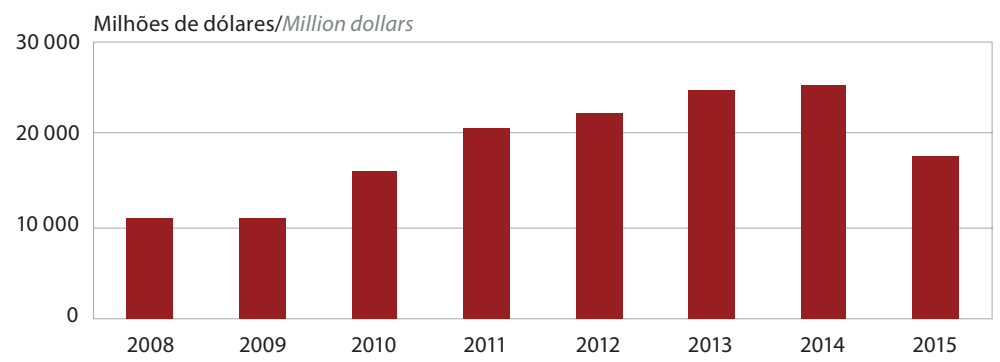

Fonte/Source: Receita e despesa cambial turística. Dados e fatos: estudos, pesquisas e dados sobre o setor de turismo. Brasília, DF: Ministério do Turismo, [2016]. Disponível em/Available from: <http://dadosefatos. turismo.gov.br>. Acesso em: maio 2017/Cited: May 2017. 


\section{Gráfico 16.3 - Receita da balança de pagamentos da conta-turismo - 2008-2015}

Graph 16.3 - Revenue in the balance of payments of tourism account -2008-2015

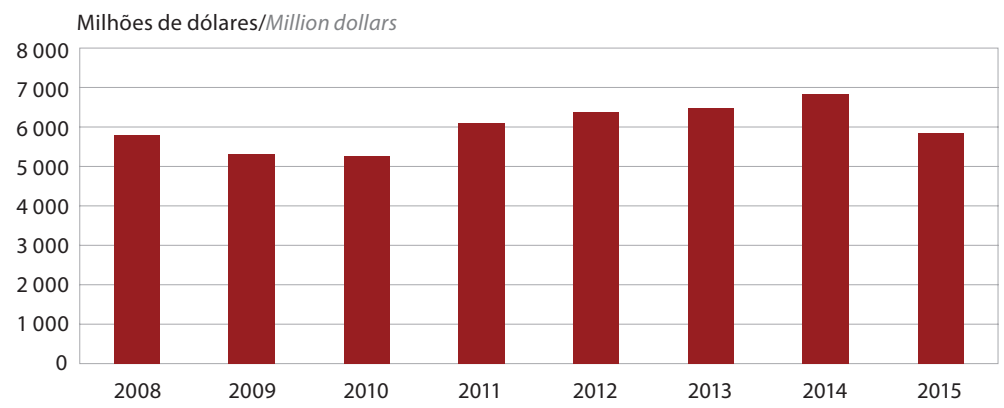

Fonte/Source: Receita e despesa cambial turística. Dados e fatos: estudos, pesquisas e dados sobre o setor de turismo. Brasília, DF: Ministério do Turismo, [2016]. Disponível em/Available from: <http://dadosefatos. turismo.gov.br>. Acesso em: maio 2017/Cited: May 2017.

\section{Gráfico 16.4 - Saldo da balança de pagamentos da conta-turismo e taxa de câmbio - 2006-2015 \\ Graph 16.4 - Balance of tourism account and exchange rate - 2006-2015}

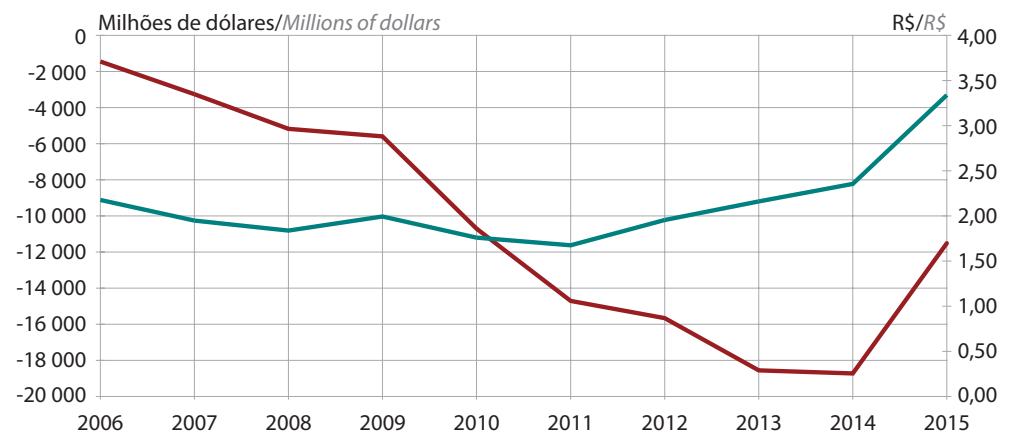

- Saldo da conta-turismo Ballance of tourism account

Taxa de câmbio - Livre - Dólar americano (venda)
Média de período - anual
Exchange rate - Free - USD (sale) - Annual average

Fonte/Source: Receita e despesa cambial turística. Dados e fatos: estudos, pesquisas e dados sobre o setor de turismo. Brasília, DF: Ministério do Turismo, [2016]. Disponível em/Available from: <http://dadosefatos. turismo.gov.br>. Acesso em: maio2017/Cited: May 2017. 